\title{
Efficacy and safety outcomes of oral anticoagulants and antiplatelet drugs in the secondary prevention of venous thromboembolism: systematic review and network meta-analysis
}

\begin{abstract}
Objective To summarise and compare the efficacy and safety of various oral anticoagulants (dabigatran, rivaroxaban, apixaban, and vitamin $\mathrm{K}$ antagonists) and antiplatelet agents (acetylsalicylic acid) for the secondary prevention of venous thromboembolism.

Design Systematic review and network meta-analysis.

Data sources Literature search using Medline (1950 to present), Embase (1980 to present), and the Cochrane Register of Controlled Trials using the OVID interface. Publications from potentially relevant journals were also searched by hand.

Review methods Randomised controlled trials of patients receiving anticoagulants, antiplatelet drugs, or placebo or observation for secondary prevention of venous thromboembolism. Selected outcomes were rates of recurrent venous thromboembolism and major bleeding. Two reviewers independently extracted data onto standardised forms.

Results 12 articles met our inclusion criteria, with 11999 patients evaluated for efficacy and 12167 for safety. All treatments reduced the risk of recurrent venous thromboembolism. Compared with placebo or observation, vitamin $\mathrm{K}$ antagonists at a standard adjusted dose (target international normalised ratio 2.0-3.0) showed the highest risk difference (odds ratio $0.07 ; 95 \%$ credible interval 0.03 to 0.15 ) and acetylsalicylic acid showed the lowest risk difference $(0.65 ; 0.39$ to 1.03$)$. Risk of major bleeding was higher with a standard adjusted dose of vitamin $\mathrm{K}$ antagonists $(5.24 ; 1.78$ to 18.25$)$ than with placebo or observation. Fatal
\end{abstract}

recurrent venous thromboembolism and fatal bleeding were rare. Detailed subgroup and individual patient level data were not available.

Conclusions All oral anticoagulants and antiplatelet agents investigated in this analysis were associated with a reduced recurrence of venous thromboembolism compared with placebo or observation, although acetylsalicylic acid was associated with the lowest risk reduction. Vitamin $\mathrm{K}$ antagonists given at a standard adjusted dose was associated with the greatest risk reduction in recurrent venous thromboembolism, but also the greatest risk of major bleeding.

\section{Introduction}

Venous thromboembolism (VTE), comprising deep vein thrombosis, pulmonary embolism, or both, is the third most common cardiovascular disorder. ${ }^{1-7}$ VTE is a potentially fatal yet preventable and treatable condition with the use of anticoagulation therapy.

The American College of Chest Physicians currently recommends an initial three months of anticoagulant treatment for patients with acute VTE. ${ }^{8}$ A recent systematic review and meta-analysis has compared the efficacy and safety of the new oral anticoagulants (direct Xa inhibitors rivaroxaban and apixaban) and a direct thrombin inhibitor (dabigatran) with those of vitamin $\mathrm{K}$ antagonists (VKA) during this acute treatment period. ${ }^{9}$ For the initial treatment of VTE, there was no difference observed in the rates of recurrent VTE between patients treated with the new oral anticoagulants or VKA. 
However, a reduction in the rates of major bleeding episodes was reported for patients receiving rivaroxaban. ${ }^{9}$

Patients with a transient and reversible risk factor for VTE (that is, a cast, surgery, immobilisation, or recent trauma) have a low annual risk of recurrent VTE after three months of oral anticoagulation and can safely discontinue anticoagulant treatment. ${ }^{10-15}$ Patients with an unprovoked VTE have a higher risk of recurrence and hence could warrant longer anticoagulation treatment. The American College of Chest Physicians currently recommends considering long term treatment in patients with unprovoked VTE and low risk of bleeding episodes. ${ }^{8}$ However, physicians and patients are often reluctant to consider long term treatment with VKA owing to the risks of bleeding, the need for regular monitoring, and lifestyle adjustments as long as treatment is continued.

Recently, new oral anticoagulants (rivaroxaban, apixaban, and dabigatran) and antiplatelet agents (acetylsalicylic acid (ASA)) have been evaluated for long term secondary prevention of recurrent VTE in patients at high risk of recurrence. ${ }^{16-20}$ These alternatives may offer a simplified approach to anticoagulation and a better harm profile than VKA. However, before the adoption of new anticoagulants or antiplatelet strategies for long term secondary prevention of VTE in patients with unprovoked VTE, the trade-off between recurrent VTE prevention and bleeding associated with these agents needs to be explored and compared to help doctors determine the optimal management strategy.

We performed a systematic review and network meta-analysis of the literature to quantify, summarise, and compare the rates of recurrent VTE and major bleeding episodes for antiplatelet drugs and different anticoagulant agents for the secondary prevention of recurrent VTE.

\section{Methods}

\section{Data sources and searches}

We conducted a systematic literature search strategy to identify potential studies on Medline (1950 to present), Embase (1980 to present), and the Cochrane Register of Controlled Trials using the OVID interface. Publications from potentially relevant journals were also searched by hand. The search protocol is documented online in the PROSPERO registry

(CRD42013003489). Web appendix 1 includes the systematic search strategy. There were no restrictions on language, publication year, or type of publication. References of included studies and narrative reviews were searched for potential studies.

\section{Study selection}

Using a structured question format to aid our literature search strategy, we reviewed all abstracts. Potentially relevant articles were reviewed in full length to ensure that they satisfied all of the following criteria:

- Prospective enrolment of consecutive patients with objectively confirmed, symptomatic. deep vein thrombosis or pulmonary embolism treated for a minimum of three months with anticoagulant treatment

- Patients randomised to receive an antiplatelet drug (ASA), an oral anticoagulant drug (VKA, rivaroxaban, apixaban, dabigatran, or ximelagatran), or a placebo or observation for secondary prevention of VTE

- One or more of the primary or secondary outcomes were reported.
Studies were excluded if patients were risk stratified at the end of the initial anticoagulation period, and if studies included asymptomatic VTE.

\section{Outcome measures}

The primary outcome measures were recurrent VTE and major bleeding episodes. Recurrent VTE was defined as a new non-compressible segment of the compression leg vein on ultrasound imaging, a new intraluminal filling defect on venography, a newly abnormal result on the impedance plethysmography test, a new high probability on ventilation/perfusion scanning, or a new filling defect in the pulmonary artery on computed tomography or pulmonary angiography. A major bleeding episode was defined as clinically overt bleeding that was associated with at least one of the following (International Society on Thrombosis and Haemostasis definition): a fall in haemoglobin levels of $20 \mathrm{~g} / \mathrm{L}$ or more; transfusion of at least two units of packed red blood cells; involvement of the intracranial or retroperitoneal space or a body cavity; death ${ }^{21}$; or as defined by the investigators of each study.

Secondary outcome measures included fatal recurrent VTE and fatal bleeding episodes. Fatal recurrent VTE was diagnosed by autopsy, a high probability ventilation/perfusion scan or new intraluminal filling defect detected on computed tomography or venography before death, or a high clinical suspicion of fatal pulmonary embolism as defined by the investigators of each study. A fatal bleeding episode was defined as a major bleeding episode directly leading to death.

\section{Data extraction and quality assessment}

Two reviewers (LAC, MC) independently assessed eligibility of articles identified in the initial search strategy for inclusion in the review. They discussed those papers deemed potentially eligible, independently extracted data (baseline characteristics, definition of outcomes, numbers of events) using a standardised data abstraction form, and assessed studies' methodological quality using the risk of bias assessment tool from the Cochrane Handbook for randomised trials. ${ }^{22}$

\section{Data synthesis and analysis}

Outcomes were allocated according to the intention to treat principle. Only outcomes occurring during the time period that patients received study drugs, placebo, or observation were included within the analyses.

Bayesian network meta-analyses and direct, frequentist, pairwise meta-analyses were conducted for all outcomes. We did Bayesian network meta-analyses using a binomial likelihood model. ${ }^{23}$ Network meta-analyses were performed on two different evidence networks. The primary analysis was based on a network where different agents (and doses) were treated as a separate node (ASA $100 \mathrm{mg}$ daily, standard adjusted dose VKA (target international normalised ratio 2.0-3.0), low dose VKA (1.5-2.0), apixaban $2.5 \mathrm{mg}$ and $5 \mathrm{mg}$ twice daily, rivaroxaban $20 \mathrm{mg}$ daily, dabigatran $150 \mathrm{mg}$ twice daily, and ximelagatran $24 \mathrm{mg}$ twice daily; fig $1 \Downarrow$ ).

A secondary evidence network of drug class was also constructed, to compare the effects of direct thrombin inhibitors (dabigatran and ximelagatran), direct Xa inhibitors (rivaroxaban and apixaban), VKA (excluding low dose), ASA $100 \mathrm{mg}$ daily, and placebo or observation. We constructed all evidence networks using NodeXL. ${ }^{24}$ Odds ratios and $95 \%$ credible intervals were modelled using Markov chain Monte Carlo methods. We used adjusted continuity corrections of 0.5 to 
account for studies with no events. ${ }^{25}$ The absolute risk difference per 100 patients treated each year for each outcome was also calculated, ${ }^{26}{ }^{27}$ based on median rates of all placebo arms for both recurrent VTE (10.1 per 100 patient years) and major bleeding (0.3). Icon arrays using the absolute event rates showed the benefits and harms of secondary thromboprophylaxis with the different agents. We calculated the probability that each drug was the most efficacious regimen by counting the proportion of iterations of the Markov chain in which each drug had the highest odds ratio. ${ }^{23}$ Random effects network meta-analyses with informative priors for heterogeneity variances were conducted for the analyses. ${ }^{28}{ }^{29} \mathrm{We}$ also conducted fixed and random effects models with vague priors. Assessment of model fit was based on comparison of residual deviance to the number of unconstrained data points and assessment of the deviance information criterion. ${ }^{23-31}$ To ensure convergence, we assessed trace plots and the Brooks-Gelman-Rubin statistic. ${ }^{32}$ Analyses were performed using WinBUGS software (MRC Biostatistics Unit).

A network meta-analysis also requires that studies are sufficiently similar in order to pool their results. ${ }^{334}$ We assessed available study and patient characteristics to ensure similarity and to investigate the potential effect of heterogeneity on effect estimates. A priori subgroup analysis was conducted to adjust for differences in study duration. We also did a priori sensitivity analysis using placebo and observation as separate nodes within the evidence network, to ensure that they could be combined. Sensitivity analysis removing ximelagatran from the evidence network was performed because the drug has been withdrawn from the market. We assessed inconsistency by comparing statistics for the deviance and deviance information criterion in fitted consistency and inconsistency models. ${ }^{33}$ Additionally, the results from our network meta-analysis were qualitatively compared with direct, frequentist, pairwise estimates. We did frequentist pairwise meta-analyses using $\mathrm{R}$ (R Language and Environment for Statistical Computing).

\section{Results}

In our literature search, we identified 636 citations and deemed 13 records as potentially eligible (web appendix 2). ${ }^{16-41}$ Two studies initially identified as abstracts were published within the same article at the time of analysis (12 articles). ${ }^{20}$ Eight studies were randomised, placebo controlled trials ${ }^{16-41}$; two compared observation with anticoagulant treatment with VKA $^{3740}$; and three compared different types of anticoagulant regimens. ${ }^{20-39}$ One trial compared two active treatments and placebo. ${ }^{19}$ Table $1 \Downarrow$ shows baseline characteristics of the included studies.

The sample size ranged from 162 to 2856 people, with a median sample size of 780 . The median follow-up period was 14.3 months (range 6-37.2 months). Two studies each treated patients with $\mathrm{ASA}^{17}{ }^{18}$ or dabigatran ${ }^{20}$ whereas one study each assessed rivaroxaban, apixaban (two doses), and ximelagatran. ${ }^{16-41}$ All other trials evaluated VKA. Most patients evaluated in these trials had unprovoked VTE as the indication for continuing anticoagulation or continuing to receive placebo or undergo observation. The trials WODIT PE,${ }^{40}$ EINSTEIN-EXT,,${ }^{16}$ and AMPLIFY-EXT ${ }^{19}$ included $57 \%, 74 \%$, and more than $90 \%$ of patients with unprovoked events, respectively. DURAC $\mathrm{II}^{35}$ and Thrive III ${ }^{41}$ did not report proportion of patients with provoked events. All remaining studies enrolled only patients with unprovoked VTE (table 1).

Web appendix 3 reports on quality assessment. Overall, a low risk of bias was identified. All studies provided adequate sequence generation, reported outcomes completely, and were free of selective reporting bias. Ten studies were designed as double blind, randomised controlled trials. ${ }^{16-41}$ Three studies had an open label design, ${ }^{35-40}$ of which two had independent, blinded outcome assessment but unclear allocation concealment. ${ }^{3740}$

\section{Recurrent VTE}

The analysis on recurrent VTE included 11999 patients. One trial was excluded from the recurrent VTE analyses because the number of events occurring while patients were receiving VKA could not be extracted from the original manuscript. ${ }^{40}$ Table $2 \Downarrow$ and figure $2 \Downarrow$ present the results of the Bayesian network meta-analyses. In the network meta-analysis, all treatments decreased the recurrence of VTE compared with placebo or observation. Standard adjusted dose VKA had the highest absolute risk difference and ASA the lowest absolute risk difference (table 2). Standard adjusted dose VKA and dabigatran were associated with the highest probability of being the best therapy (66\% and 17\%, respectively) among all treatments (web appendix 4).

Standard adjusted dose VKA (odds ratio 0.11 (95\% credible interval 0.04 to 0.27 )), dabigatran, apixaban $5 \mathrm{mg}$, apixaban 2.5 $\mathrm{mg}$, and rivaroxaban decreased the risk of recurrent VTE, compared with ASA (fig $3 \Downarrow$ ). Compared with low dose VKA, standard adjusted dose VKA reduced the risk of recurrent VTE ( 0.25 ( 0.10 to 0.58 ); fig 3 ). With the exception of the comparison between ASA and placebo or observation, the estimates of effect derived from the direct frequentist pairwise comparisons aligned well with those obtained from the network meta-analysis in both direction and magnitude (web appendices 5 and 6). Web appendix 6 presents a detailed explanation for the potential discrepancy between ASA and placebo results. Results for most class level analyses also aligned with those reported previously in the treatment level analysis.

Subgroup analyses, performed to account for heterogeneity due to study duration, yielded results that were more favourable for ASA than those obtained from the primary analysis (web appendix 7). However, results for ASA were still less pronounced than those reported for other treatments (standard adjusted dose VKA, low intensity VKA, and dabigatran) that remained in the evidence network (web appendix 7). Sensitivity analysis excluding ximelagatran from the analysis did not change the results reported (web appendix 8).

\section{Major bleeding episodes}

The analysis on major bleeding episodes included 12167 patients. Table 2 outlines the odds ratios of major bleeding events in patients receiving antiplatelet or anticoagulant treatments compared with those receiving placebo or observation. Compared with placebo or observation, an increased risk of major bleeding was associated with the use of standard adjusted dose VKA, rivaroxaban, and low intensity VKA (table 2, web appendix 9). Apixaban $5 \mathrm{mg}$ was associated with the highest probability of being the best treatment (69\%) for reducing the risk of major bleeding events among all treatments (web appendix 4). Apixaban $5 \mathrm{mg}$ twice daily seemed to be associated with a reduction in major bleeding compared with standard adjusted dose VKA, dabigatran, rivaroxaban (odds ratio 0.01 (95\% credible interval 0.00001 to 0.4$)$ ), and low intensity VKA (0.04 (0.0009 to 0.53$)$; fig 3$)$. The estimates of effect derived from the direct, frequentist pairwise comparisons aligned well with those obtained from the network meta-analysis (web appendix 5). Similarly, results for most class level analyses 
also aligned with those reported previously in the treatment level analysis.

\section{Fatal recurrent VTE and fatal bleeding episodes}

Fatal recurrent VTE and fatal bleeding episodes were rare. Web appendix 10 reports pooled rates of fatal events. One trial was excluded from the pooled event rates $(n=227)$ because it compared different lengths of treatment using the same anticoagulation regimen of standard dose adjusted VKA. ${ }^{35}$ Sixteen $(0.13 \%)$ of 12090 patients had a fatal recurrent VTE, of whom nine $(56 \%)$ received placebo or observation only. Similarly, five $(0.04 \%)$ of 11765 patients had a fatal bleeding episode, of whom four $(80 \%)$ received placebo or observation. There were no differences among treatments in fatal recurrent VTE or fatal bleeding events.

\section{Discussion}

This systematic review and network meta-analysis determined the rates of recurrent VTE and major bleeding associated with use of antiplatelet agents and oral anticoagulants for the long term secondary prevention of VTE. All the oral anticoagulants (standard and low dose VKA, dabigatran, rivaroxaban, and apixaban (both $2.5 \mathrm{mg}$ and $5 \mathrm{mg}$ twice daily)) reduced the risk of recurrent VTE among patients requiring secondary prevention of VTE. Although ASA was associated with a reduction in the risk of VTE, the results were less pronounced than those observed for all dosing strategies of VKA and the new oral anticoagulants. The results also varied depending on the type of analysis conducted (web appendix 6). Standard adjusted dose VKA, dabigatran, rivaroxaban and apixaban (both $2.5 \mathrm{mg}$ and $5 \mathrm{mg}$ twice daily) seemed to be associated with a reduced risk of recurrence compared with ASA. Standard adjusted dose VKA was also associated with a decreased risk of recurrence relative to low dose VKA. However, standard adjusted dose VKA was associated with an increased risk of major bleeding compared with placebo or observation. These risks for recurrent VTE and major bleeding events are key pieces of information to help doctor assess the benefit-harm balance of the various agents in secondary prevention and tailor their therapeutic approaches accordingly.

\section{Novel findings}

The risk of recurrent VTE and major bleeding are fundamental considerations in a doctor's recommendation for secondary prevention of VTE and which agent to choose. We provide estimates on symptomatic recurrent VTE (a patient important outcome) that are clinically relevant and that form the basis of guideline recommendations in clinical practice. ${ }^{82}$ Recurrent VTE might be fatal or lead to important clinical complications such as post-thrombotic syndrome and chronic thromboembolic pulmonary hypertension, which are associated with a substantial reduction in quality of life. ${ }^{43-45}$ Our analysis also provides estimates of treatment effects for all antiplatelet agents and oral anticoagulants, whether or not they have been directly compared in randomised controlled trials. We conducted both treatment and class level analyses to provide the most information to guide clinical decision making. Although ximelagatran is not commercially available, the drug was included in our analysis because it improved the precision of the other estimates. However, separate analyses excluding ximelagatran showed similar results to those reported here (web appendix 8).

Our study confirms previous data indicating that anticoagulants are effective in reducing the rate of recurrent VTE among patients with previous events. It also provides reliable estimates on consequent risks of major bleeding, which individual studies often could not estimate, given the limited sample size. Figure $4 \Downarrow$ shows icon arrays illustrating the absolute benefit to harm of different agents for secondary prevention of VTE. Standard adjusted dose VKA seemed to be the most effective agent at reducing recurrence but was also associated with more major bleeding events (figs 2 and 3). The net clinical benefit seemed to favour the oral anticoagulants (standard adjusted dose VKA, dabigatran, and apixaban) when compared with placebo or observation and ASA (fig 4). However, the role of ASA as a secondary preventative agent remains unclear; further studies need to establish this benefit to harm profile. In addition, the individual components of the net clinical benefit (recurrent VTE and major bleeding events) might not carry the same case fatality rate. $^{46}$

The most important outcome of secondary prevention studies is the effect on fatal recurrent VTE and fatal bleeding events. The number of fatal events reported in the included studies was infrequent (table 1, web appendix 10), leading to imprecise pooled point estimates with large $95 \%$ credible intervals. A clinical trial examining the trade-off of secondary prevention of VTE with mortality is not feasible, owing to the large sample size needed to detect a likely small mortality difference between treatments. The rates of recurrent VTE and major bleeding events need to be interpreted in combination with the case fatality rates to allow a better estimate of benefit to harm in the secondary prevention of VTE. Although the case fatality rates of recurrent VTE and major bleeding events during the acute treatment of VTE have been described, ${ }^{46}$ these rates during secondary prevention remain unknown.

\section{Limitations of the study}

Our study had several limitations. Firstly, the length of follow-up varied across studies. Trials assessing ASA and VKA had longer follow-up periods than studies evaluating new oral anticoagulants (dabigatran, rivaroxaban, apixaban). We performed a subgroup analysis (web appendix 7) to account for the difference in treatment duration. The effects for ASA were more pronounced in the subgroup analysis than in the primary analysis; however, they were still less favourable than both dosing strategies of VKA and dabigatran. The comparative efficacy of ASA versus the direct Xa inhibitors remains unclear. Although further studies need to establish the benefit-harm balance of ASA compared with VKA and the new oral anticoagulants, ASA use for secondary prevention of recurrent VTE may be valuable in patients with arterial disease who are at low to moderate risk of recurrent VTE. ASA could be an attractive option to doctors and patients over VKA for the prevention of recurrent arterial and venous events, given its simplicity and ease of use. ASA monotherapy poses a safer alternative to the combination of ASA and a new oral anticoagulant, which have shown higher risks of bleeding. ${ }^{47-49}$ Secondly, the new oral anticoagulants have not been adequately studied to inform on benefits and harms of extending their use beyond one year for long term secondary prevention of recurrent VTE.

Thirdly, patient level longitudinal data are needed to establish more robust conclusions in specific patient populations. Other risk factors-including index event (deep vein thrombosis or pulmonary embolism), presence of risk factors for VTE (that is, provoked index events), age, body mass index, and length of initial anticoagulation - could influence case fatality rates of recurrent VTE and bleeding events. But in the absence of patient level data, this cannot be explored in sufficient detail. Three 
studies included patients with provoked index VTE. ${ }^{16-40}$ Some recurrent VTE rates might be slightly biased as a result of the inclusion of these patients. Fourthly, most studies included within the network meta-analysis were placebo controlled trials, with only three "head to head" trials and two trials comparing different dosing strategies (dabigatran $v$ VKA, VKA standard $v$ low intensity doses, and apixaban $2.5 v 5 \mathrm{mg}$ twice daily). ${ }^{20-39}$ Future direct comparison trials are needed to confirm our findings.

In addition, limited data were available for some of the anticoagulant agents to include in the analysis. For example, only one study assessed rivaroxaban, and no major bleeding was reported in the placebo arm during the follow-up period of 265 days. Adjusted continuity corrections of 0.5 were used in the analyses, resulting in uncertain effect estimates for rivaroxaban. Therefore, larger studies of longer duration are needed to provide more definitive conclusions regarding the comparative risk of bleeding with rivaroxaban with other treatments (web appendix 9). Another limitation was that we did not account for cost and patient preferences for each outcome (recurrent VTE $v$ major bleeding). In view of the similar rates of patient important outcomes among the various sources of secondary prevention strategies, further evaluation of existing data is needed to determine the most cost effective approach. The event rates reported in our analysis could inform cost effectiveness analyses. It should also be noted that other potentially important safety parameters (such as coronary artery events and hepatotoxicity) were not evaluated within this review. Finally, the large majority of patients in this study was extracted from randomised controlled trials, and therefore are not generalisable to all patients with VTE, since patients with more severe disease are likely to be excluded from these clinical trials. Further studies in the "real world" setting are needed.

\section{Conclusions}

The rates of recurrent VTE and major bleeding events should be taken into account when assessing the efficacy and safety of different treatment strategies for secondary prevention for VTE. Other factors-including individual patient risk factors, case fatality, costs, lifestyle modifications, burden of laboratory monitoring, and patient values and preferences - should also be considered when making recommendations to patients regarding anticoagulant treatment.

\section{Contributors: LAC and CC contributed equally to this study. LAC} conceived the study, performed the systematic review, data extraction, analysed the data, and drafted the manuscript. CC performed the data analysis and drafted the manuscript. GLG, EG, PSW, MAR, DC, TC, and GW analysed the data and reviewed the manuscript for important intellectual content. MC conceived the study, performed the systematic review, data extraction, and analysis, and drafted the manuscript. All authors had full access to the data and take responsibility for the integrity of the data and accuracy of the analysis. MC is guarantor.

Funding: The study did not receive specific funding. MC is a recipient of a New Investigator Award from the Heart and Stroke Foundation of Canada and holds a T2 research chair in cancer and thrombosis from the University of Ottawa. CC is a recipient of a Vanier Canada Graduate Scholarship from the Canadian Institutes of Health Research and has received funding from Canadian Network and Centre for Trials Internationally (CANNeCTIN). MAR is the recipient of a Career Scientist Award from the Heart and Stroke Foundation of Ontario. PSW is a recipient of a Canada research chair in venous thromboembolism.

Competing interests: All authors have completed the ICMJE uniform disclosure form at www.icmje.org/coi_disclosure.pdf (available on request from the corresponding author) and declare: no support from any organisation for the submitted work; $\mathrm{MC}$ is a recipient of a New Investigator Award from the Heart and Stroke Foundation of Canada and holds a T2 research chair in cancer and thrombosis from the University of Ottawa; CC is a recipient of a Vanier CGS from the Canadian Institutes of Health Research and had received funding from CANNeCTIN; MAR is the recipient of a Career Scientist Award from the Heart and Stroke Foundation of Ontario; PSW is a recipient of a Canada research chair in venous thromboembolism; no other relationships or activities that could appear to have influenced the submitted work.

Ethical approval: Not required.

Data sharing: No additional data available.

1 Cohen AT, Agnelli G, Anderson FA, Arcelus JI, Bergqvist D, Brecht JG, et al. Venous thromboembolism (VTE) in Europe. The number of VTE events and associated morbidity and mortality. Thromb Haemost 2007:98:756-64.

2 Ageno W, Prandoni P, Romualdi E, Ghirarduzzi A, Dentali F, Pesavento R, et al. The metabolic syndrome and the risk of venous thrombosis: a case-control study. J Thromb Haemost 2006;4:1914-8.

3 Heit JA. The epidemiology of venous thromboembolism in the community: implications for prevention and management. J Thromb Thrombolysis 2006;21:23-9.

4 White RH. The epidemiology of venous thromboembolism. Circulation 2003;107:14-8

5 Prins MH, Marchiori A. Risk of recurrent venous thomboembolism-expanding the frontier. Thromb Haemost 2002;87:1-3.

6 Silverstein MD, Heit JA, Mohr DN, Petterson TM, O'Fallon WM, Melton LJ 3rd. Trends in the incidence of deep vein thrombosis and pulmonary embolism: a 25-year population-based study. Arch Intern Med 1998;158:585-93.

7 Anderson FA Jr, Wheeler HB, Goldberg RJ, Hosmer DW, Patwardhan NA, Jovanovic B, et al. A population-based perspective of the hospital incidence and case-fatality rates of deep vein thrombosis and pulmonary embolism. The Worcester study. Arch Intern Med 1991;151:933-8.

8 Kearon C, Akl EA, Comerota AJ, Prandoni P, Bounameaux H, Goldhaber SZ, et al. Antithrombotic therapy for VTE disease: antithrombotic therapy and prevention of thrombosis, 9th ed. American College of Chest Physicians Evidence-Based Clinical Practice Guidelines. Chest 2012;141:e419-94S.

9 Fox BD, Kahn SR, Langleben D, Eisenberg MJ, Shimony A. Efficacy and safety of novel oral anticoagulants for treatment of acute venous thromboembolism: direct and adjusted indirect meta-analysis of randomised controlled trials. BMJ 2012;345:e7498.

10 Baglin T, Luddington R, Brown K, Baglin C. Incidence of recurrent venous thromboembolism in relation to clinical and thrombophilia risk factors: prospective cohort study. Lancet 2003:362:523-6.

11 Heit JA, Mohr DN, Silverstein MD, Petterson TM, O’Fallon WM, Melton LJ 3rd. Predictors of recurrence after deep vein thrombosis and pulmonary embolism: a population-based cohort study. Arch Intern Med 2000;160:761-8.

12 Prandoni P, Lensing AWA, Cogo A, Cuppini S, Villalta S, Carta M, et al. The long-term clinical course of acute deep venous thrombosis. Ann Intern Med 1996;125:1-7.

13 Research Committee of the British Thoracic Society. Optimum duration of anticoagulation for deep-vein thrombosis and pulmonary embolism. Lancet 1992;340:873-6.

14 Segal JB, Streiff MB, Hoffman LV, Thornton K, Bass EB. Management of venous thromboembolism: a systematic review for a practice guideline. Ann Intern Med 2007;146:211-22.

15 Iorio A, Kearon C, Filippucci E, Marcucci M, Macura A, Pengo V, et al. Risk of recurrence after a first episode of symptomatic venous thromboembolism provoked by a transient risk factor: a systematic review. Arch Intern Med 2010;170:1710-6.

16 Einstein Investigators, Bauersachs R, Berkowitz SD, Brenner B, Buller HR, Decousus H, et al. Oral rivaroxaban for symptomatic venous thromboembolism. N Engl J Med 2010;363:2499-510.

17 Becattini C, Agnelli G, Schenone A, Eichinger S, Bucherini E, Silingardi M, et al. Aspirin for preventing the recurrence of venous thromboembolism. N Engl J Med 2012;366:1959-67.

18 Brighton TA, Eikelboom JW, Mann K, Mister R, Gallus A, Ockelford P, et al. Low-dose aspirin for preventing recurrent venous thromboembolism. N Engl J Med 2012;367:1979-87.

19 Agnelli G, Buller HR, Cohen A, Curto M, Gallus AS, Johnson M, et al. Apixaban for extended treatment of venous thromboembolism. N Engl J Med 2013;368:699-708.

20 Schulman S, Kearon C, Kakkar AK, Schellong S, Eriksson H, Baanstra D, et al. Extended use of dabigatran, warfarin, or placebo in venous thromboembolism. $N$ Engl $\mathrm{J} \mathrm{Med}$ 2013;368:709-18.

21 Schulman S, Kearon C. Definition of major bleeding in clinical investigations of antihemostatic medicinal products in non-surgical patients. J Thromb Haemost 2005;3:692-4.

22 Higgins JPT. Cochrane Handbook for Systematic Reviews of Interventions Version 5.0.2. 2009. www.cochrane-handbook.org.

23 Dias S, Welton NJ, Sutton AJ, Ades A. NICE DSU technical support document 2: a generalised linear modelling framework for pairwise and network meta-analysis of randomised controlled trials. 2011. www.nicedsu.org.uk.

24 Hansen D, Shneiderman B, Smith MA. Analyzing social media networks with NodeXL: insights from a connected world. Elsevier, 2010.

25 Sweeting MJ, Sutton AJ, Lambert PC. What to add to nothing? Use and avoidance of continuity corrections in meta-analysis of sparse data. Stat Med 2004;23:1351-75.

26 Fleurence RL, Hollenbeak CS. Rates and probabilities in economic modelling: transformation, translation and appropriate application. Pharmacoeconomics 2007;25:3-6.

27 Zhang J, Yu KF. What's the relative risk? A method of correcting the odds ratio in cohort studies of common outcomes. JAMA 1998:280:1690-1.

28 Turner RM, Davey J, Clarke MJ, Thompson SG, Higgins JP. Predicting the extent of heterogeneity in meta-analysis, using empirical data from the Cochrane Database of Systematic Reviews. Int J Epidemiol 2012;41:818-27.

29 Thorlund K, Thabane L, Mills EJ. Modelling heterogeneity variances in multiple treatment comparison meta-analysis-are informative priors the better solution? BMC Med Res Methodol 2013;13:2. 


\section{What is already known on this topic}

Long term anticoagulation for the secondary prevention of venous thromboembolism remains controversial

\section{Recently, novel oral anticoagulants and antiplatelet drugs have been evaluated for the secondary prevention of} venous thromboembolism

\section{What this study adds}

Among the studies included in this systematic review, all novel oral anticoagulants and antiplatelet drugs investigated were associated with a reduced recurrence of venous thromboembolism compared with placebo or observation

ASA was associated with the lowest risk reduction

Vitamin $\mathrm{K}$ antagonists, at a standard adjusted dose, was associated with the greatest risk reduction in recurrent venous thromboembolism but also with the greatest risk of major bleeding

30 Cipriani A, Furukawa TA, Salanti G, Geddes JR, Higgins JP, Churchill R, et al. Comparative efficacy and acceptability of 12 new-generation antidepressants: a multiple-treatments meta-analysis. Lancet 2009;373:746-58

31 Spiegelhalter DJ, Best NG, Carlin BP, Van der Linde A. Bayesian measures of model complexity and fit. J Roy Stat Soc Ser B (Stat Methodol) 2002;64:583-639.

32 Spiegelhalter D, Thomas A, Best N. WinBUGS user manual. MRC Biostatistics Unit 2, 2004

33 Dias S, Welton NJ, Sutton AJ, Caldwell DM, Lu G, Ades AE. Evidence synthesis for decision making 4 : inconsistency in networks of evidence based on randomized controlled trials. Med Decis Making 2013;33:641-56.

34 Jansen JP, Naci H. Is network meta-analysis as valid as standard pairwise meta-analysis? It all depends on the distribution of effect modifiers. BMC Med 2013;11:159.

35 Schulman S, Granqvist S, Holmstrom M, Carlsson A, Lindmarker P, Nicol P, et al. The duration of oral anticoagulant therapy after a second episode of venous thromboembolism. N Engl J Med 1997;336:393-8.

36 Kearon C, Gent M, Hirsh J, Weitz J, Kovacs MJ, Anderson DR, et al. A comparison of three months of anticoagulation with extended anticoagulation for a first episode of idiopathic venous thromboembolism. N Engl J Med 1999;340:901-7.

37 Agnelli G, Prandoni P, Santamaria MG, Bagatella P, lorio A, Bazzan M, et al. Thre months versus one year of oral anticoagulant therapy for idiopathic deep venous thrombosis. Warfarin Optimal Duration Italian Trial Investigators. N Engl J Med 2001;345:165-9.

38 Ridker PM, Goldhaber SZ, Danielson E, Rosenberg Y, Eby CS, Deitcher SR, et al. Long-term, low-intensity warfarin therapy for the prevention of recurrent venous thromboembolism. N Engl J Med 2003;348:1425-34.

39 Kearon C, Ginsberg JS, Kovacs MJ, Anderson DR, Wells PS, Julian JA, et al. Comparison of low-intensity warfarin therapy with conventional-intensity warfarin therapy for long-term prevention of recurrent venous thromboembolism. N Engl J Med 2003;349:631-9.

40 Agnelli G, Prandoni P, Becattini C, Silingardi M, Taliani MR, Miccio M, et al. Extended oral anticoagulant therapy after a first episode of pulmonary embolism. Ann Intern Med 2003;139:19-25

41 Schulman S, Wahlander K, Lundstrom T, Billing Classon S, Eriksson H. Secondary prevention of venous thromboembolism with the oral direct thrombin inhibitor ximelagatran. N Engl J Med 2003;349:1713-21.

42 Guyatt GH, Eikelboom JW, Gould MK, Garcia DA, Crowther M, Murad MH, et al. Approach to outcome measurement in the prevention of thrombosis in surgical and medical patients:
Antithrombotic Therapy and Prevention of Thrombosis, 9th ed. American College of Chest Physicians Evidence-Based Clinical Practice Guidelines. Chest 2012;141:e185-94S.

43 Kahn SR, Shrier I, Julian JA, Ducruet T, Arsenault L, Miron MJ, et al. Determinants and time course of the postthrombotic syndrome after acute deep venous thrombosis. Ann Intern Med 2008;149:698-707.

44 Kahn SR, Shbaklo H, Lamping DL, Holcroft CA, Shrier I, Miron MJ, et al. Determinants of health-related quality of life during the 2 years following deep vein thrombosis. J Thromb Haemost 2008;6:1105-12.

45 Riedel M, Stanek V, Widimsky J, Prerovsky I. Longterm follow-up of patients with pulmonary thromboembolism. Late prognosis and evolution of hemodynamic and respiratory data. Chest 1982;81:151-8.

46 Carrier M, Le Gal G, Wells PS, Rodger MA. Systematic review: case-fatality rates of recurrent venous thromboembolism and major bleeding events among patients treated for venous thromboembolism. Ann Intern Med 2010;152:578-89.

47 Dans AL, Connolly SJ, Wallentin L, Yang S, Nakamya J, Brueckmann M, et al. Concomitant use of antiplatelet therapy with dabigatran or warfarin in the Randomized Evaluation of Long-Term Anticoagulation Therapy (RE-LY) trial. Circulation 2013;127:634-40.

48 Mega JL, Braunwald E, Wiviott SD, Bassand JP, Bhatt DL, Bode C, et al. Rivaroxaban in patients with a recent acute coronary syndrome. N Engl J Med 2012;366:9-19.

49 Alexander JH, Lopes RD, James S, Kilaru R, He Y, Mohan P, et al. Apixaban with antiplatelet therapy after acute coronary syndrome. N Engl J Med 2011;365:699-708.

50 Salanti G, Ades AE, loannidis JP. Graphical methods and numerical summaries for presenting results from multiple-treatment meta-analysis: an overview and tutorial. $J$ Clin Epidemiol 2011;64:163-71

51 Higgins JP, Thompson SG, Spiegelhalter DJ. A re-evaluation of random-effects meta-analysis. J R Stat Soc Ser A Stat Soc 2009;172:137-59.

\section{Accepted: 2 August 2013}

\section{Cite this as: BMJ 2013:347: 55133}

This is an Open Access article distributed in accordance with the Creative Commons Attribution Non Commercial (CC BY-NC 3.0) license, which permits others to distribute, remix, adapt, build upon this work non-commercially, and license their derivative works on different terms, provided the original work is properly cited and the use is non-commercial. See: http://creativecommons.org/licenses/by-nc/3.0/. 


\section{Tables}

\begin{tabular}{|c|c|c|c|c|c|c|c|c|c|c|c|}
\hline Study (patients) & $\begin{array}{l}\text { Treatment (No of } \\
\text { patients) }\end{array}$ & Design & $\begin{array}{c}\text { Treatment } \\
\text { duration } \\
\text { (mean) }\end{array}$ & $\begin{array}{l}\text { Mean } \\
\text { age } \\
\text { (years)† }\end{array}$ & Men (\%)† & $\begin{array}{c}\text { Proximal } \\
\text { DVT as } \\
\text { index } \\
\text { event }(\%) \dagger\end{array}$ & $\begin{array}{c}\text { Unprovoked } \\
\text { VTE (\%)† }\end{array}$ & $\begin{array}{c}\text { Recurrent } \\
\text { VTE } \\
\text { events† }\end{array}$ & $\begin{array}{l}\text { Fatal } \\
\text { recurrent } \\
\text { VTE } \\
\text { events† }\end{array}$ & $\begin{array}{c}\text { Major } \\
\text { bleeding } \\
\text { events }\end{array}$ & $\begin{array}{c}\text { Fatal } \\
\text { bleeding } \\
\text { events } †\end{array}$ \\
\hline \multicolumn{12}{|c|}{ Standard dose VKA } \\
\hline $\begin{array}{l}\text { DURAC } \|^{35} \text { (all } \\
\text { VTE) }\end{array}$ & $\begin{array}{l}\text { Standard dose VKA: } \\
\text { fixed duration } \\
\text { ( } \mathrm{n}=111) \text { v extended } \\
\text { duration }(\mathrm{n}=116)\end{array}$ & $\begin{array}{l}\text { Open label, } \\
\text { randomised }\end{array}$ & $\begin{array}{c}\text { Fixed } \\
\text { duration, } \\
7.7 \\
\text { months; } \\
\text { extended } \\
\text { duration, } \\
42.7 \\
\text { months }\end{array}$ & $65 / 64 /-$ & $63 / 59 /-$ & $72 / 66 /-$ & $\mathrm{NR} / \mathrm{NR} /$ - & $23 / 3 /-$ & $0 / 1 /-$ & $1 / 10 /-$ & $0 / 2 /-$ \\
\hline LAFIT $^{36}$ (all VTE) & $\begin{array}{c}\text { Placebo }(n=83) v \\
\text { standard dose VKA } \\
(n=79)\end{array}$ & $\begin{array}{l}\text { Double blind, } \\
\text { randomised }\end{array}$ & 10 months & $58 / 59 /-$ & $53 / 68 /-$ & $73 / 76 /-$ & $100 / 100 /-$ & $17 / 1 /-$ & $1 / 0 /-$ & $0 / 3 /-$ & $0 / 0 /-$ \\
\hline $\begin{array}{l}\text { WODIT DVT }{ }^{37} \\
\text { (DVT only) }\end{array}$ & $\begin{array}{l}\text { Observation }(n=133) \\
v \text { standard dose } \\
\text { VKA }(n=134)\end{array}$ & $\begin{array}{l}\text { Open label, } \\
\text { randomised }\end{array}$ & 9 months & $68 / 67 /-$ & $61 / 55 /-$ & 100/100/- & $100 / 100 /-$ & $11 / 1 /-$ & $0 / 0 /-$ & $1 / 4 /-$ & $1 / 0 /-$ \\
\hline $\begin{array}{l}\text { WODIT } \\
\text { PE }^{40} \text { (PE only) }\end{array}$ & $\begin{array}{c}\text { Observation }(\mathrm{n}=91) \\
v \text { standard dose } \\
\text { VKA }(\mathrm{n}=90)\end{array}$ & $\begin{array}{l}\text { Open label, } \\
\text { randomised }\end{array}$ & 9 months & $61 / 63 /-$ & $\mathrm{NR} / \mathrm{NR} /-$ & $0 / 0 /-$ & $57 / 55 /-$ & $\mathrm{NR} / \mathrm{NR} /$ - & $0 / \mathrm{NR} /-$ & $1 / 2 /-$ & $0 / 0 /-$ \\
\hline \multicolumn{12}{|c|}{ Low intensity VKA } \\
\hline $\begin{array}{l}\text { ELATE }^{39} \text { (all } \\
\text { VTE) }\end{array}$ & $\begin{array}{l}\text { VKA: standard dose } \\
(\mathrm{n}=369) v \text { low dose } \\
(\mathrm{n}=369)\end{array}$ & $\begin{array}{c}\text { Double blind, } \\
\text { randomised }\end{array}$ & 2.4 years & $57 / 57 /-$ & 53/57/- & $62 / 68 /-$ & $100 / 100 /-$ & $6 / 16 /-$ & $2 / 1 /-$ & $8 / 9 /-$ & $0 / 0 /-$ \\
\hline $\begin{array}{l}\text { PREVENT }{ }^{38} \text { (all } \\
\text { VTE) }\end{array}$ & $\begin{array}{c}\text { Placebo }(n=253) v \\
\text { low dose VKA } \\
(n=255)\end{array}$ & $\begin{array}{l}\text { Double blind, } \\
\text { randomised }\end{array}$ & 2.1 years & 53/53/- & $53 / 53 /-$ & $\mathrm{NR} / \mathrm{NR} /$ - & $100 / 100 /-$ & $37 / 14 /-$ & $2 / 0 /-$ & $2 / 5 /-$ & $1 / 0 /-$ \\
\hline \multicolumn{12}{|c|}{ Direct thrombin inhibitors } \\
\hline $\begin{array}{l}\text { Thrive III }{ }^{41} \text { (all } \\
\text { VTE) }\end{array}$ & $\begin{array}{l}\text { Placebo }(n=611) v \\
\text { ximelagatran } 24 \mathrm{mg} \\
\text { twice daily }(\mathrm{n}=612)\end{array}$ & $\begin{array}{l}\text { Double blind, } \\
\text { randomised }\end{array}$ & 505 days & $58 / 56 /-$ & $51 / 54 /-$ & $64 / 66 /-$ & $\mathrm{NR} / \mathrm{NR} /-$ & $71 / 12 /-$ & $3 / 0 /-$ & $5 / 6 /-$ & $0 / 0 /-$ \\
\hline $\begin{array}{l}\text { RESONATE }{ }^{20} \text { (all } \\
\text { VTE) }\end{array}$ & $\begin{array}{l}\text { Placebo }(\mathrm{n}=662) v \\
\text { dabigatran } 150 \mathrm{mg} \\
\text { twice daily }(\mathrm{n}=681)\end{array}$ & $\begin{array}{l}\text { Double blind, } \\
\text { randomised }\end{array}$ & 6 months & $56 / 56 /-$ & $55 / 56 /-$ & $67 / 63 /-$ & $100 / 100 /-$ & $37 / 3 /-$ & $0 / 0 /-$ & $0 / 2 /-$ & $0 / 0 /-$ \\
\hline $\begin{array}{l}\text { REMEDY }{ }^{20} \text { (all } \\
\text { VTE) }\end{array}$ & $\begin{array}{c}\text { Standard dose VKA } \\
\quad(\mathrm{n}=1426) v \\
\text { dabigatran } 150 \mathrm{mg} \\
\text { twice daily }(\mathrm{n}=1430)\end{array}$ & $\begin{array}{l}\text { Double blind, } \\
\text { randomised }\end{array}$ & 18 months & $54 / 55 /-$ & $61 / 61 /-$ & $65 / 66 /-$ & $100 / 100 /-$ & $18 / 26 /-$ & $1 / 1 /-$ & $25 / 13 /-$ & $1 / 0 /-$ \\
\hline \multicolumn{12}{|c|}{ Factor Xa inhibitors } \\
\hline $\begin{array}{l}\text { EINSTEIN-EXT }{ }^{16} \\
\text { (all VTE) }\end{array}$ & $\begin{array}{l}\text { Placebo }(\mathrm{n}=594) v \\
\text { rivaroxaban } 20 \mathrm{mg} \\
\text { daily }(\mathrm{n}=602)\end{array}$ & $\begin{array}{l}\text { Double blind, } \\
\text { randomised }\end{array}$ & $\begin{array}{l}265 \\
\text { days }\end{array}$ & $58 / 58 /-$ & $57 / 59 /-$ & $60 / 64 /-$ & $74 / 73 /-$ & $42 / 8 /-$ & $1 / 0 /-$ & $0 / 4 /-$ & $0 / 0 /-$ \\
\hline $\begin{array}{l}\text { AMPLIFY-EXT } \\
\text { (all VTE) }\end{array}$ & $\begin{array}{l}\text { Placebo }(\mathrm{n}=829) v \\
\text { apixaban } 5 \mathrm{mg} \text { twice } \\
\text { daily }(\mathrm{n}=813) v \\
\text { apixaban } 2.5 \mathrm{mg} \\
\text { twice daily }(\mathrm{n}=840)\end{array}$ & $\begin{array}{l}\text { Double blind, } \\
\text { randomised }\end{array}$ & $\begin{array}{c}12 \\
\text { months }\end{array}$ & $57 / 56 / 57$ & $57 / 58 / 58$ & $67 / 65 / 65$ & $91 / 91 / 93$ & $73 / 14 / 14$ & $0 / 0 / 0$ & $4 / 1 / 2$ & $0 / 0 / 0$ \\
\hline \multicolumn{12}{|l|}{ Low dose ASA } \\
\hline $\begin{array}{l}\text { WARFASA }{ }^{17} \text { (all } \\
\text { VTE) }\end{array}$ & $\begin{array}{l}\text { Placebo }(n=197) v \\
\text { ASA } 100 \mathrm{mg} \text { daily } \\
(\mathrm{n}=205)\end{array}$ & $\begin{array}{l}\text { Double blind, } \\
\text { randomised }\end{array}$ & $\begin{array}{c}23.9 \\
\text { months }\end{array}$ & $62 / 62 /-$ & $62 / 66 /-$ & $66 / 60 /-$ & $100 / 100 /-$ & $39 / 23 /-$ & $1 / 1 /-$ & $1 / 1 /-$ & $\mathrm{NR} / \mathrm{NR} /-$ \\
\hline $\begin{array}{l}\text { ASPIRE }^{18} \text { (all } \\
\text { VTE) }\end{array}$ & $\begin{array}{l}\text { Placebo }(n=411) v \\
\text { ASA } 100 \text { mg daily } \\
\quad(n=411)\end{array}$ & $\begin{array}{c}\text { Double blind, } \\
\text { randomised }\end{array}$ & $\begin{array}{c}37.2 \\
\text { months }\end{array}$ & $54 / 55 /-$ & $54 / 55 /-$ & $56 / 57 /-$ & $100 / 100 /-$ & $73 / 57 /-$ & $1 / 1 /-$ & $6 / 8 /-$ & $2 / 0 /-$ \\
\hline
\end{tabular}

$\mathrm{DVT}=$ deep vein thrombosis; $\mathrm{NR}=$ not reported; $\mathrm{PE}=$ pulmonary embolism.

*Group $1 v$ group 2 v group 3 (where applicable). 
Table 1 (continued)

\begin{tabular}{|c|c|c|c|c|c|c|c|c|c|c|c|}
\hline tients) & $\begin{array}{c}\text { Treatment (No of } \\
\text { patients) }\end{array}$ & esign & $\begin{array}{c}\text { Treatment } \\
\text { duration } \\
\text { (mean) }\end{array}$ & $\begin{array}{c}\text { Mean } \\
\text { age } \\
\text { (years)† }\end{array}$ & Men (\%)† & $\begin{array}{c}\text { Proximal } \\
\text { DVT as } \\
\text { index } \\
\text { event }(\%) \dagger\end{array}$ & $\begin{array}{l}\text { Unprovoked } \\
\text { VTE (\%)† }\end{array}$ & $\begin{array}{c}\text { Recurrent } \\
\text { VTE } \\
\text { events† }\end{array}$ & $\begin{array}{l}\text { Fatal } \\
\text { recurrent } \\
\text { VTE } \\
\text { events } \dagger\end{array}$ & $\begin{array}{c}\text { Major } \\
\text { bleeding } \\
\text { events† }\end{array}$ & $\begin{array}{c}\text { Fatal } \\
\text { bleeding } \\
\text { events }\end{array}$ \\
\hline
\end{tabular}

†Group 1/group 2/group 3.

$\ddagger$ Median age. 


\begin{tabular}{|c|c|c|c|c|}
\hline Intervention & $\begin{array}{l}\text { Risk of recurrent VTE } \\
\text { (odds ratio }(95 \% \mathrm{Crl}) \text { ) }\end{array}$ & $\begin{array}{c}\text { No of events of recurrent VTE per } \\
100 \text { patients treated each year } \\
\text { (absolute risk difference ( } 95 \% \\
\text { Crl)) }\end{array}$ & $\begin{array}{l}\text { Risk of major bleeding } \\
\text { (odds ratio }(95 \% \mathrm{Crl}) \text { ) }\end{array}$ & $\begin{array}{c}\text { No of major bleeding episode per } \\
100 \text { patients treated each year } \\
\text { (absolute risk difference ( } 95 \% \\
\text { Crl)) }\end{array}$ \\
\hline $\begin{array}{l}\text { Standard adjusted dose } \\
\text { VKA }\end{array}$ & 0.07 (0.03 to 0.15$)$ & 8.8 fewer ( 8 fewer to 9.3 fewer) & $5.24(1.78$ to 18.25$)$ & 1.3 more ( 0.2 more to 5 more) \\
\hline ASA 100 mg daily* & 0.65 (0.39 to 1.03$)$ & 3.1 fewer ( 5.5 fewer to 0.2 more) & $1.29(0.4$ to 4.08$)$ & 0.1 more ( 0.2 fewer to 1 more) \\
\hline $\begin{array}{l}\text { Dabigatran } 150 \mathrm{mg} \text { twice } \\
\text { daily }\end{array}$ & $0.09(0.04$ to 0.21$)$ & 8.6 fewer ( 7.3 fewer to 9.2 fewer) & 2.79 (0.79 to 11.69$)$ & 0.6 more ( 0.1 fewer to 3.2 more) \\
\hline Apixaban 5 mg twice daily & $0.18(0.08$ to 0.38$)$ & 7.7 fewer (5.6 fewer to 8.7 fewer) & $0.19(0.01$ to 1.78$)$ & 0.26 fewer ( 0.32 fewer to 0.2 more $)$ \\
\hline Apixaban 2.5 mg twice daily & 0.17 (0.08 to 0.36$)$ & 7.8 fewer (5.8 fewer to 8.8 fewer) & $0.46(0.05$ to 2.82$)$ & 0.2 fewer ( 0.3 fewer to 0.6 more) \\
\hline Rivaroxaban 20 mg daily & $0.17(0.06$ to 0.41$)$ & 7.8 fewer ( 5.3 fewer to 8.9 fewer) & $20.79(1.31$ to 14230$) \dagger$ & 5.7 more (0.1 more to 62.1 more) \\
\hline Low intensity VKA & $0.28(0.13$ to 0.57$)$ & 6.6 fewer ( 3.8 fewer to 8.2 fewer) & $4.77(1.38$ to 19.49$)$ & 1.2 more ( 0.11 more to 5.4 more) \\
\hline \multicolumn{5}{|c|}{$\begin{array}{l}\text { Data are based on comparisons of each intervention with placebo or observation. Crl=credible interval. } \\
\text { *Estimates are derived from random effects, Bayesian network meta-analysis, which treats between study variance as an informative prior (log normal distribution). } \\
\text { Estimates differ from those reported in frequentist direct meta-analysis in ASPIRE and web appendix } 5 \text { (both reported significant differences in favour of ASA) } \\
\text { because between study variance is treated as a constant in frequentist analyses. Web appendix } 6 \text { reports detailed estimates for the ASA versus placebo comparison. } \\
\text { †Only one study investigated rivaroxaban for major bleeding and contained a zero cell ( } 0 \text { of } 590 \text { people receiving placebo and four of } 598 \text { receiving rivaroxaban), } \\
\text { which resulted in uncertain estimates of effect. }\end{array}$} \\
\hline
\end{tabular}




\section{Figures}

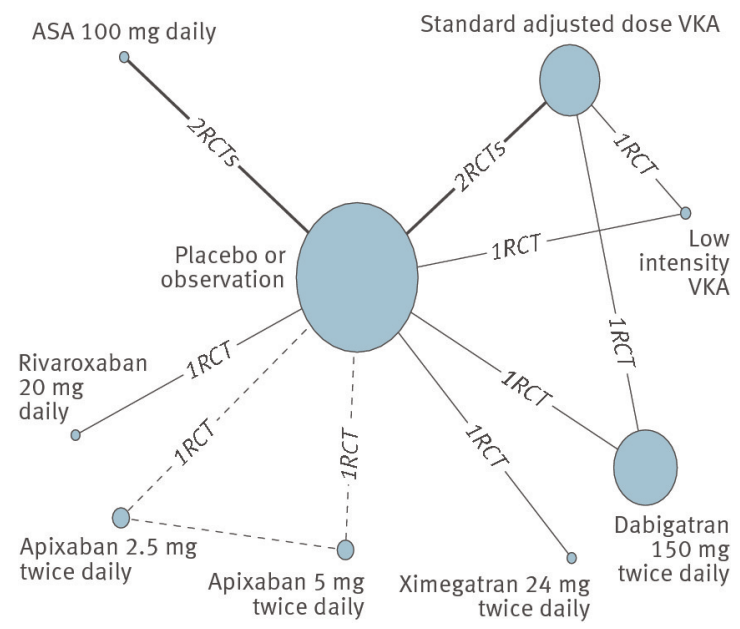

Fig 1 Evidence network for recurrence of venous thromboembolism. The width of lines for each connection in the evidence network are proportional to the number of randomised controlled trials (RCTs) comparing each pair of treatments. The size of each treatment node is proportional to the number of randomised participants (sample size). Dotted line=three arm RCT in the evidence network. The analysis includes ximelagatran to improve precision of effect estimates; however, the results are not reported because ximelagatran is not commercially available

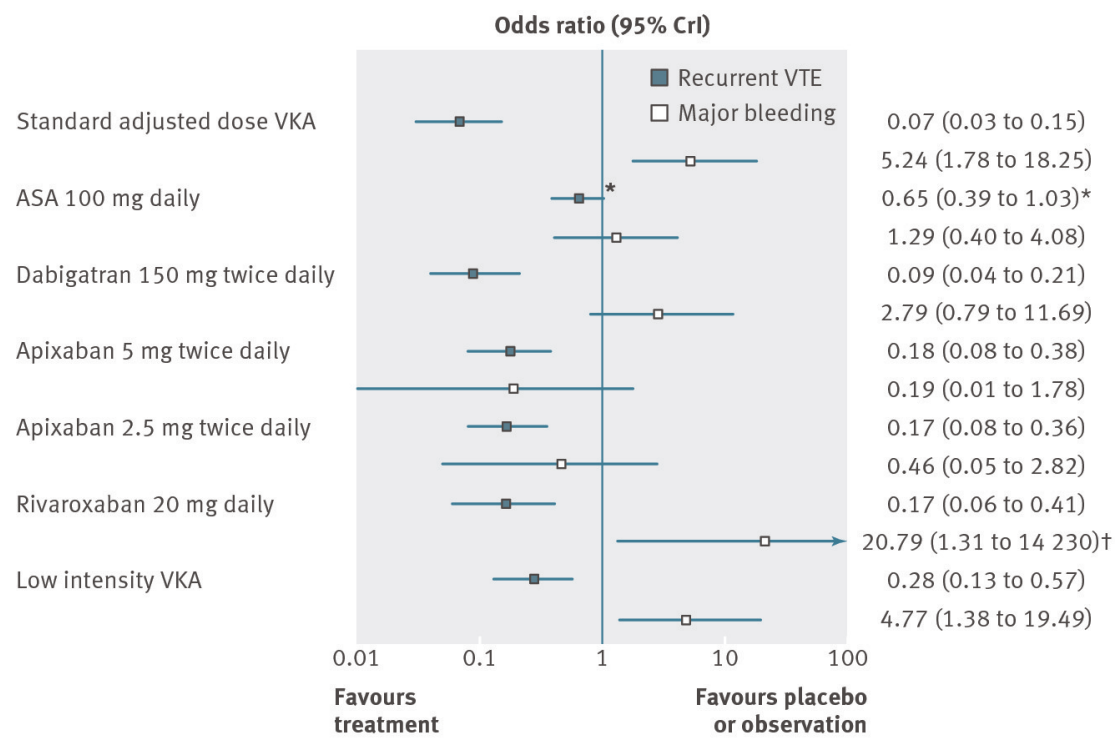

Fig 2 Odds ratio (95\% credible interval) for recurrent VTE and major bleeding episodes in Bayesian network meta-analysis versus placebo or observation. Crl=credible interval. *Estimates are derived from random effects, Bayesian network meta-analysis, which treats between study variance as an informative prior (log normal distribution). Estimates differ from those reported in frequentist direct meta-analysis in ASPIRE and web appendix 5 (both reported significant differences in favour of ASA) because between study variance is treated as a constant in frequentist analyses. Web appendix 6 reports detailed estimates for the ASA versus placebo comparison. †Only one study investigated rivaroxaban for major bleeding and contained a zero cell ( 0 of 590 people receiving placebo and four of 598 receiving rivaroxaban), which resulted in uncertain estimates of effect 


\begin{tabular}{|c|c|c|c|c|c|c|c|}
\hline $\begin{array}{l}\text { Placebo or } \\
\text { observation }\end{array}$ & $\begin{array}{c}\frac{5.24}{(1.78 \text { to } 18.25)} \\
.\end{array}$ & $\begin{array}{c}1.29 \\
(0.40 \text { to } 4.08)\end{array}$ & $\begin{array}{c}2.79 \\
\text { (0.79 to } 11.69)\end{array}$ & $\begin{array}{c}0.19 \\
\text { (0.01 to } 1.78)\end{array}$ & $\begin{array}{c}0.46 \\
(0.05 \text { to } 2.82)\end{array}$ & $\frac{20.79}{(1.31 \text { to } 14230)}$ & (1.38 to 19.49) \\
\hline$\underline{(0.03 \text { to } 0.15)}$ & $\begin{array}{l}\text { Standard } \\
\text { adjusted } \\
\text { dose VKA }\end{array}$ & $\begin{array}{c}0.24 \\
(0.05 \text { to } 1.21)\end{array}$ & $\begin{array}{c}0.54 \\
(0.23 \text { to } 1.29)\end{array}$ & $(0.001$ to 0.45$)$ & $(0.01$ to 0.70$)$ & $\begin{array}{c}4.03 \\
(0.17 \text { to } 3031)\end{array}$ & $\begin{array}{c}0.92 \\
(0.32 \text { to } 2.60)\end{array}$ \\
\hline $\begin{array}{c}0.65 \\
(0.39 \text { to } 1.03)^{\star}\end{array}$ & $\frac{9.14}{(3.66 \text { to } 24.91)}$ & $\begin{array}{c}\text { ASA } \\
100 \text { mg daily }\end{array}$ & $\begin{array}{c}2.21 \\
(0.39 \text { to } 13.34)\end{array}$ & $\begin{array}{c}0.14 \\
\text { (0 to } 1.85)\end{array}$ & $\begin{array}{c}0.35 \\
(0.03 \text { to } 3.15)\end{array}$ & $\begin{array}{c}16.73 \\
(0.77 \text { to } 11840)\end{array}$ & $\begin{array}{c}3.76 \\
(0.68 \text { to } 22.21)\end{array}$ \\
\hline$\frac{0.09}{(0.04 \text { to } 0.21)}$ & $\begin{array}{c}1.32 \\
\text { (0.64 to } 2.63)\end{array}$ & $\underline{(0.05 \text { to } 0.37)}$ & $\begin{array}{l}\text { Dabigatran } \\
150 \mathrm{mg} \\
\text { twice daily }\end{array}$ & $\begin{array}{c}0.06 \\
(0.001 \text { to } 0.91)\end{array}$ & $\begin{array}{c}0.16 \\
(0.01 \text { to } 1.46)\end{array}$ & $\begin{array}{c}7.57 \\
(0.29 \text { to } 5736)\end{array}$ & $\begin{array}{c}1.72 \\
(0.44 \text { to } 6.38)\end{array}$ \\
\hline$\frac{0.18}{(0.08 \text { to } 0.38)}$ & $\begin{array}{c}2.51 \\
\text { (0.83 to } 7.94)\end{array}$ & (0.11 to 0.68$)$ & $\begin{array}{c}1.92 \\
(0.61 \text { to } 6.45)\end{array}$ & $\begin{array}{l}\text { Apixaban } \\
5 \mathrm{mg} \text { twice } \\
\text { daily }\end{array}$ & $\begin{array}{c}2.39 \\
(0.19 \text { to } 83.89)\end{array}$ & $\frac{136.5}{(2.51 \text { to } 195000)}$ & $\begin{array}{c}\frac{26.98}{(1.89 \text { to } 1108)} \\
\end{array}$ \\
\hline$\frac{0.17}{(0.08 \text { to } 0.36)}$ & $\begin{array}{c}2.43 \\
(0.80 \text { to } 7.72)\end{array}$ & $\frac{0.26}{(0.11 \text { to } 0.66)}$ & $\begin{array}{c}1.84 \\
(0.59 \text { to } 6.22)\end{array}$ & $\begin{array}{c}0.96 \\
(0.39 \text { to } 2.40)\end{array}$ & $\begin{array}{c}\text { Apixaban } \\
2.5 \text { mg twice } \\
\text { daily }\end{array}$ & (1.44 to 45740$)$ & $\frac{10.82}{(1.17 \text { to } 139.50)}$ \\
\hline$\underline{0.17}$ & $\begin{array}{c}2.41 \\
(0.69 \text { to } 8.41)\end{array}$ & $\underline{\underline{0.26}} \underline{(0.09 \text { to } 0.73)}$ & $\begin{array}{c}1.83 \\
(0.52 \text { to } 6.75)\end{array}$ & $\begin{array}{c}0.96 \\
(0.27 \text { to } 3.11)\end{array}$ & $\begin{array}{c}0.99 \\
(0.29 \text { to } 3.28)\end{array}$ & $\begin{array}{l}\text { Rivaroxaban } \\
20 \text { mg daily }^{\dagger}\end{array}$ & $\begin{array}{c}0.23 \\
\text { (0 to } 5.59)\end{array}$ \\
\hline$\underline{0.28}$ & $\begin{array}{l}\frac{3.98}{(1.73 \text { to } 9.74)} \\
\end{array}$ & $\begin{array}{c}0.43 \\
(0.18 \text { to } 1.04)\end{array}$ & $\begin{array}{c}3.03 \\
(1.15 \text { to } 8.41)\end{array}$ & $\begin{array}{c}1.59 \\
(0.54 \text { to } 4.59)\end{array}$ & $\begin{array}{c}1.64 \\
(0.56 \text { to } 4.79)\end{array}$ & $\begin{array}{c}1.67 \\
(0.52 \text { to } 5.49)\end{array}$ & $\begin{array}{c}\text { Low intensity } \\
\text { VKA }\end{array}$ \\
\hline
\end{tabular}

Fig 3 Odds ratios (95\% credible interval) from network meta-analyses for recurrence of VTE and major bleeding for all pairwise comparisons. Odd ratios for recurrence of VTE are below the diagonal line (row defining treatment $v$ column defining treatment); odds ratios for major bleeding are above the diagonal line (column defining treatment $v$ row defining treatment). To obtain odds ratios for comparisons in the opposite direction, reciprocals should be taken (for example, the odds ratio for placebo or observation compared with ASA $100 \mathrm{mg}$ daily for recurrence of VTE is $1 \div 0.65=1.54)$. Significant results are in bold and underlined. *Estimates are derived from random effects, Bayesian network meta-analysis, which treats between study variance as an informative prior (log normal distribution). Estimates differ from those reported in frequentist direct meta-analysis in ASPIRE and web appendix 5 (both reported significant differences in favour of ASA) because between study variance is treated as a constant in frequentist analyses. Web appendix 6 reports detailed estimates for the ASA versus placebo comparison. †Only one study investigated rivaroxaban for major bleeding and contained a zero cell ( 0 of 590 people receiving placebo and four of 598 receiving rivaroxaban), which resulted in uncertain estimates of effect 


\begin{tabular}{|c|c|c|c|c|}
\hline & $\begin{array}{l}\text { Placebo or } \\
\text { observation }\end{array}$ & $\begin{array}{l}\text { Standard adjusted } \\
\text { dose VKA }\end{array}$ & ASA 100 mg daily & $\begin{array}{l}\text { Dabigatran } 150 \mathrm{mg} \\
\text { twice daily }\end{array}$ \\
\hline 100 & 市市市市市市市市市市 & 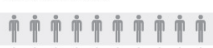 & 市市市市市市市市市市 & 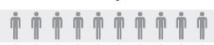 \\
\hline $\begin{array}{l}90 \\
80\end{array}$ & 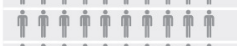 & 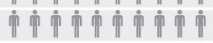 & 宋市市市宋宋市市市 & 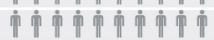 \\
\hline 80 & 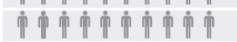 & 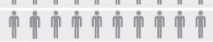 & 市市市市市市市市市 & 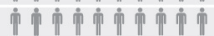 \\
\hline 70 & 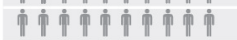 & 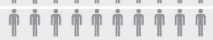 & 中市中芇中巾中市 & 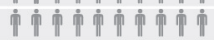 \\
\hline 60 & 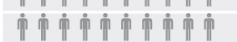 & 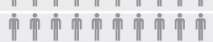 & 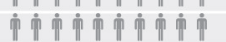 & 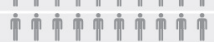 \\
\hline 50 & 宋市市市市宋市市市市 & 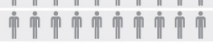 & 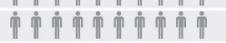 & 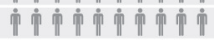 \\
\hline 40 & 市市市市市市市市 & 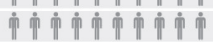 & 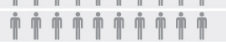 & 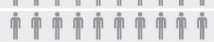 \\
\hline 30 & 市市市市市市市市市市 & 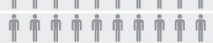 & 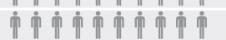 & 中市市市市市市市市 \\
\hline & 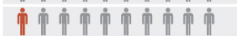 & 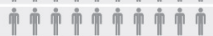 & 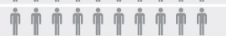 & 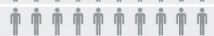 \\
\hline \multirow[t]{2}{*}{$\begin{array}{r}10 \\
0\end{array}$} & 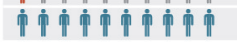 & 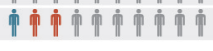 & 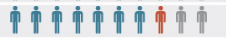 & 中市市市市市市市市 \\
\hline & $\begin{array}{l}\text { Apixaban } 5 \mathrm{mg} \text { twice } \\
\text { daily }\end{array}$ & $\begin{array}{l}\text { Apixaban } 2.5 \mathrm{mg} \\
\text { twice daily }\end{array}$ & $\begin{array}{l}\text { Rivaroxaban } 20 \mathrm{mg} \\
\text { daily* }\end{array}$ & $\begin{array}{l}\text { Low intensity } \\
\text { VKA }\end{array}$ \\
\hline 100 & 宋市宋宋宋市市市市 & 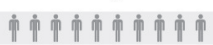 & 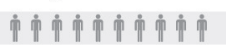 & 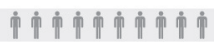 \\
\hline $\begin{array}{l}90 \\
80\end{array}$ & 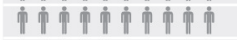 & 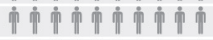 & 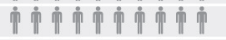 & 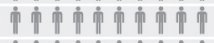 \\
\hline 70 & 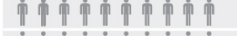 & 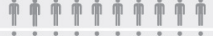 & 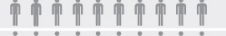 & 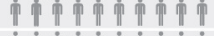 \\
\hline 60 & 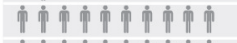 & 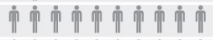 & 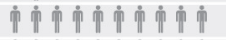 & 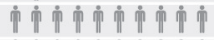 \\
\hline 50 & 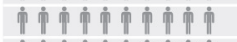 & 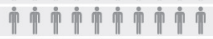 & 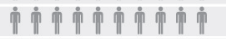 & 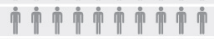 \\
\hline 40 & 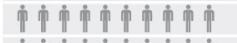 & 市市市市市宋市市市市 & 市市市市市市市市市 & 宋市市市市市市市市市 \\
\hline 30 & 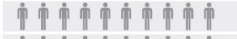 & 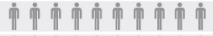 & 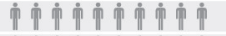 & 中方市市市市市市市 \\
\hline 20 & 市市市市市市市市市 & 宋市市市市市市市市 & 市市中市市市市市市 & 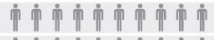 \\
\hline 10 & 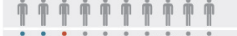 & 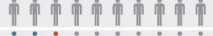 & 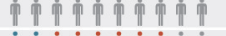 & 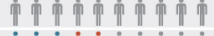 \\
\hline & 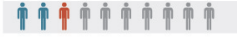 & 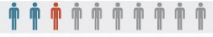 & 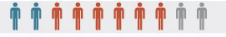 & 宋市市市市市市市市 \\
\hline
\end{tabular}

Fig 4 Icon array showing absolute risks of recurrent VTE (blue) and major bleeding episodes (red). *Only one study investigated rivaroxaban for major bleeding and contained a zero cell ( 0 of 590 people receiving placebo and four of 598 receiving rivaroxaban), which resulted in uncertain estimates of effect 